\title{
Plaque formation on the hydrophobic composite resin
}

\author{
Hideaki SHINTANI, Hisamori HAYASHIHARA, Junko MURAKAMI, \\ Jui-Shiang TUNG, Naoki SATOU and Tokio INOUE \\ Department of Operative Dentistry, Hiroshima University School of Dentistry, Minami-ku, Hiroshima \\ 734, Japan
}

Received on September 30, 1983

The adherence of oral Streptococcal cells to the hydrophobic composite resin, Microrest, and the subsequent plaque formation, were studied in vitro and in vivo.

Fewer cells adhered to Microrest than to the conventional resins, though in plaque formation in vitro no difference was observed among resins. In contrast, the plaque formation in vivo was definitely weaker in Microrest than that in Clearfil and the rate of proliferation of microorganisms on the former was slower compared to that on the latter. Therefore, some differences may exist in the physicochemical properties of surface among these resins.

Key Words: Composite Resin, Plaque, Hydrophobility

\section{INTRODUCTION}

Plaque formation on dental restorative materials are known to not only induce secondary caries or periodontal disease, but also to wear the restorative materials $(1,2)$. Although proper restorative treatment and strict oral cleaning may be necessary to circumvent these problems, the improvement of the physicochemical properties of surface of restorative resin so that plaque formation can be inhibited could be an another approach. The commonly used composite resin contains a large amount of inorganic fillers which result in rough surface of the resin by polishing.

Microparticle filled resin (MFR) recovers the smooth surface after polishing exceedingly well (3), and therefore it may be surmised that plaque formation on it is inhibited to some extent. However, Marshall (4) reported that plaque is formed even on smooth surface, e.g. on glass plate, suggesting that the smoothness of surface is not the only factor governing the bacterial cell adhesion.

Recently, monomers of composite resin have been improved and now a resin which is composed of hydrophobic monomers such as Microrest $\Sigma$ is available. Studies of the contact angle and water sorption and solubility of Microrest have clearly demonstrated its hydrophobic nature (5). In this paper the effect of the hydrophobility on plaque formation i.e., the adherence to Microrest of oral Streptococcal cells and subsequent formation, were studied in vitro and in vivo.

This study was supported in part by Grant-in Aid for Scientific Research from the Minister of Education, Science and Culture of Japan. $\$ 57470099$

Presented at the 61st General Session, IADR at Sidney, Australia, August 1-3, 1983.

$\Sigma$ GC Dental Industrial Co., Tokyo, Japan 


\section{MATERIALS AND METHOD}

The composite resins used in this study were Microrest, Silar ${ }^{I}$, Adaptic $\delta$ and Clearfils. Assay of adherence of Streptococci to composite resins in vitro:

The composite resins were mixed according to the manufactures' directions and placed on polyethylene cylindrical tubes $(5 \times 5 \mathrm{~mm})$ and left to set cured against slide glass under pressure. The tubes were hung in bacterial suspensions with orthodontic wire $(\phi 0.9 \mathrm{~mm})$.

Streptococcus mutans HS-6 and S.sanguis ATCC 10556 were obtained from the Dept. of Oral Microbiology, Hiroshima University School of Dentistry. The bacteria were grown in Tripticase soy broth (supplemented $0.5 \%$ yeast extract), harvested by centrifugation and washed twice in $0.05 \mathrm{M}$ Tris $\mathrm{HCl}$ buffered saline $(\mathrm{pH} 7.2)$, sonicated for $40 \mathrm{sec}$ and resuspended in Tris $\mathrm{HCl}$ buffer $(0.05 \mathrm{M}, \mathrm{pH} 7.2)$ to a final density of O.D. $=0.3$ at $550 \mathrm{~nm}$. In test series including pretreatment with saliva, 1-day old resin specimens were immersed in filtered $\left(0.45 \mu \mathrm{m}\right.$ membrane filterb) whole saliva for $2 \mathrm{~h}$ at $37^{\circ} \mathrm{C}$. The saliva was stimulated by the subject chewing on Parafilm $V$ and collected in ice-chilled test tubes (6). Each specimen was hung in $5.0 \mathrm{ml}$ bacterial cell suspension, incubated with shaking at 120 strokes per min for $2 \mathrm{~h}$ at $37^{\circ} \mathrm{C}$. The specimens were then rinsed with distilled water and air-dried and fixed for $30 \mathrm{~min}$ in $2.5 \%$ glutaraldehyde at $4{ }^{\circ} \mathrm{C}$.

Counting of adhered cells on resins were carried out by using a scanning electron microscope $(\operatorname{SEM} \Phi)$ or a fluorescent microscope $(\mathrm{FM} \alpha)$. Specimens for SEM were dehydrated in serial concentrations of ethanol and coated with a layer of gold. The adherent cells were counted in a field of view at a magnification of 1,500 .

Observation by FM was performed by a modified method of Imura et al. (7). After staining with acrydinorage $r$, the adherent cells were photographed and counted in the area $\left(53 \times 54.5 \mathrm{~mm}^{2}\right)$.

Counting was performed with 10 discretionary views per specimen, and experiments were performed in duplicate.

Assay of artificial plaque formation in vitro:

Specimens were prepared in pieces of $7 \times 30 \times 0.3 \mathrm{~mm}$ and orthodontic wire was applicated to hung in bacterial suspensions. S.mutans HS-6 was grown to logarithmic phase of O.D. $=0.7-0.8$ at $600 \mathrm{mn}$ in Trypticase soy broth. The bacterial suspension $(0.5 \mathrm{ml})$ was placed in each test tube containing $10 \mathrm{ml}$ of Trypticase soy broth included $5 \%$ sucrose. The specimen was hung in the test tube, incubated shaking 120 strokes per min for $18 \mathrm{~h}$ at $37^{\circ} \mathrm{C}$.

The specimens were then rinsed with distilled water once dried for $24 \mathrm{~h}$ at $37^{\circ} \mathrm{C}$ and the dry weights of plaque was measured. Five specimens were thus prepared for each resin.

$I$ 3M Co., St. Paul, Minnessota, USA

$\sigma$ Johnson \& Johnson, East Winder, New Jersey, USA

$\S$ Kuraray Co., Osaka, Japan

lb Millipore Co., Bedford, Massachusetts, USA

$V$ American Can Co., Greenwich, USA

$\Phi$ S-430, Hitachi Co., Tokyo, Japan

I BHF, Olympus Co., Tokyo, Japan

$r$ Katayama Chemical, Osaka, Japan 
Assay of adherence of oral microorganisms in vivo:

The composite resins were mixed and placed in polyethylene cylindrical tubes $(4 \times 2 \mathrm{~mm})$ left to set cured against slide glass under pressure. The specimen holder with two specimens was set in the vestibule close to the molar of two adult subjects. After 4, 8, 12, $24 \mathrm{~h}$, the specimen was removed and rinsed with distilled water once after being air-dried and suspended in $1 \mathrm{ml}$ of sterile saline. The suspension was subjected to outer sonication for $3 \mathrm{~min}$ to disrupt adherent microorganisms. The resulting suspension was then serially diluted over a range between $10^{-1}$ and $10^{-4}$ and $0.1 \mathrm{ml}$ aliquots placed on Mitis-Salivarius agar and incubated at $37^{\circ} \mathrm{C}$.

\section{RESULTS AND DISCUSSION}

Streptococcal adherence in vitro: Microrest and Silar, which are MFR, permit fewer cells to adhere compared to the conventional resins (Figures 1 and 2) and the difference was statistically siginificant $(\mathrm{p}<0.05)$.

Generally, the factors governing bacterial accumulation on solid surface are van der Walls forces and ionic interactions which are defined by the properties of both bacteria and resin surface, and the insoluble extra-bacterial polysaccharides seem to be an important factor in the former (8). The hydrophobic nature of Microrest was suggested by the studies of contact angle, water sorption (5) and staining test (9), and it was surmised that the low

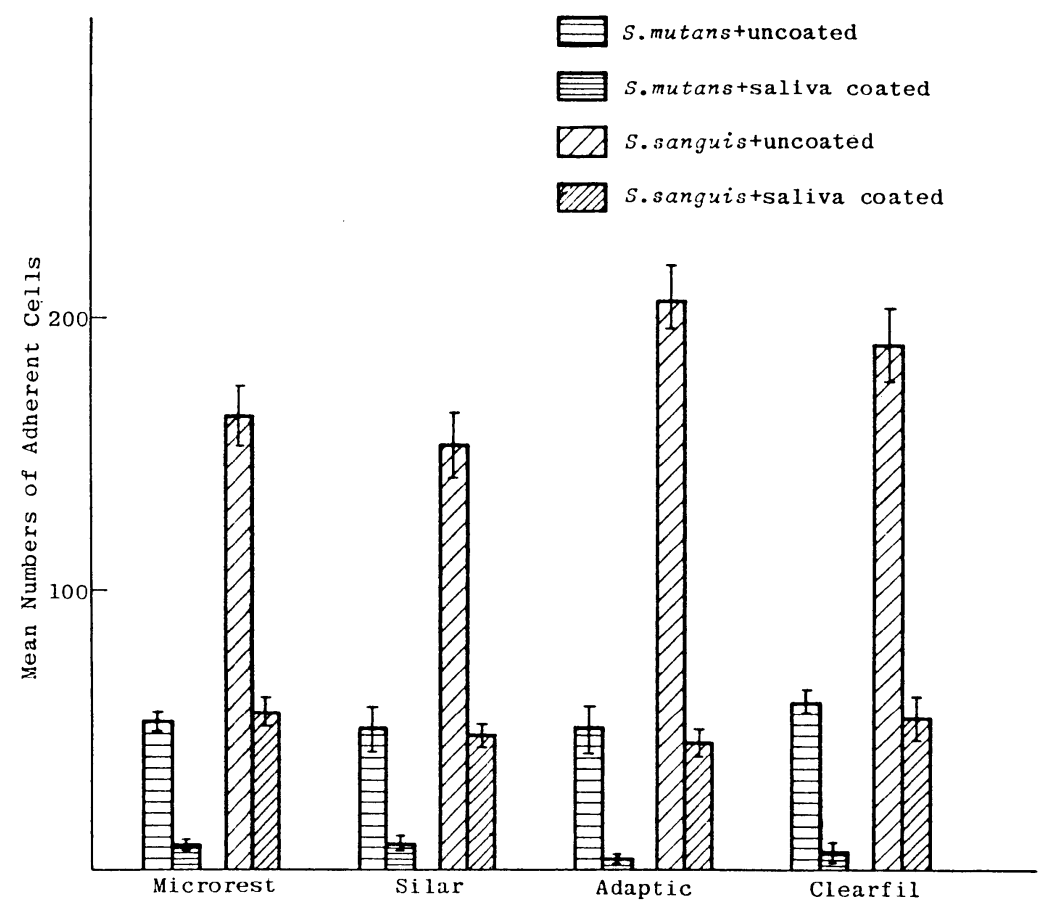

Figure 1 The number of adherent cells for each material Adherent cells of $S$. mutans HS-6 and $S$. sanguis ATCC 10556 were counted under SEM. 


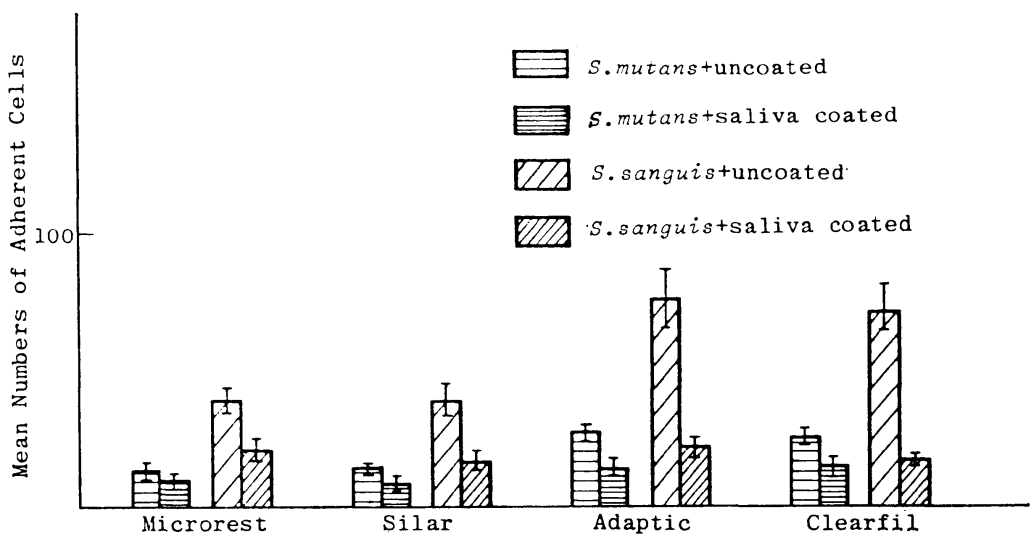

Figure 2 The number of adherent cells for each material Adherent cells of $S$. mutans HS-6 and $S$. sanguis ATCC 10556 were counted under FM.

wet ability could lower the plaque formation, but from the present data, seemed to be not clearly affected. Such a hydrophobic nature of Microrest is attributed to the chemical structure of the resin. Microrest binder resin is mainly composed of Bis-MPEPP (2,2-bis $\{(4-m e t h a c r y l o x y p o l v e t h o x y)$ phenyl $\}$ propane) wherein the average amount of ethylene oxide units $(m+n)$ present satisfies the relation $2.2 \leqq m+n \leqq 3.0$. Since monomer does not contain the hydroxyl group as in Bis-GMA monomer, Bis-MPEPP has a lower water sorption than those derived from Bis-GMA.

When resins were pretreated with saliva, the differences of adhering capacity among resins were less pronounced, though the number of adherent cells varied to some extent (Figures 1 and 2). These results suggest that the adherence to resins of bacterial cells are also influenced by pellicle which adhere to resins prior to bacteria.

In vitro plaque formation, no difference was observed in the abilities to form plaque on the surface of each resin (Figure 3). These results are similar to those reported by Clayton and his coworkers (10) who noted little differences in plaque accumulation among the three kinds of materials, viz., ceramic material, gold alloy and acrylic resin, all of which had smooth surfaces. It seems, therefore, if a plaque layer is once formed, the differences of surface nature of resins may be lessened. Regarding the ease or difficulty of removing accumulated plaque, we suspect that physicochemical properties of the material have affect on it.

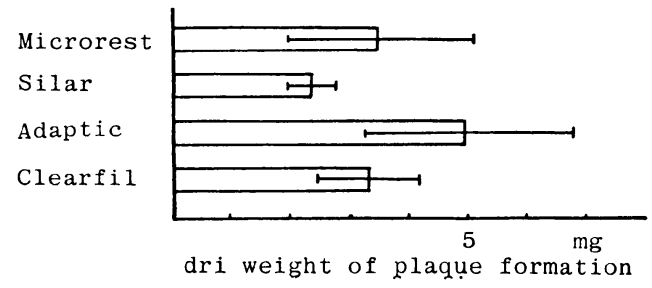

Figure 3 Plaque formation on resins in vivo 


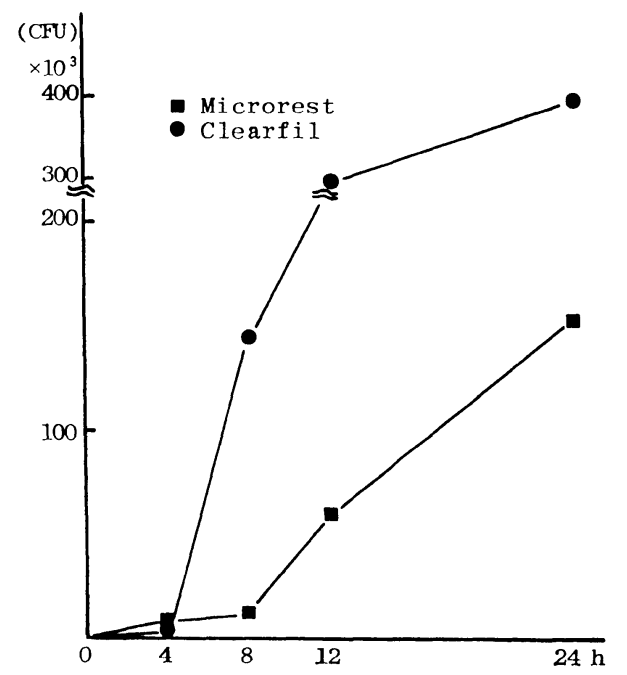

Figure 4 Number of colony-forming units (CFU) obtained from each specimen

Studies in vivo: In studies with oral microorganism in vivo, Microrest and Clearfil showed almost the same colony counts when the experiment was carried out for $4 \mathrm{~h}$. However, the number of cells adhering to the former was definitely lower than that to the latter when the experiment was continued for $24 \mathrm{~h}$ (Figure 4). The plaque formation is a complex process beginning with the adherence of bacteria to a pellicle which coats the surface of teeth or resins, followed by other bacterial adhesion on that. The process is antagonized by the self-cleaning factors in the oral cavity and the consequence of such an antagonism results in the plaque formation. The fact that Microrest shows lower bacterial cell adherence compared to Clearfil may be attributed to its hydrophobic nature, The improvement of the nature of the resin surface will be an important aspect in preventing secondary caries or periodontal disease.

\section{CONCLUSION}

Adherence to Microrest, a hydrophobic resin, of oral streptococcal cells and subsequent formation of plaque was studies in vitro and in vivo.

The results obtained are as follows.

1) The total number of cells of S.mutans HS-6 and S.sanguis 10556 adhering to Microrest was less than to the conventional resins.

2) When resins were pretreated with saliva, the differences in adhering capacity among resins were less significant, though the number of adherent cells varied.

3) Plaque formation on the individual resins in vitro revealed a similar tendency.

4) In studies of oral microorganism in vivo, the number of adhering cells to Microrest was lower than that to Clearfil and the rate of bacterial growth was slower compared to that observed with the latter. 


\section{REFERENCES}

1) Ando, S.: A study on corrosion tendencies of dental amalgam -Effect of artficial plaque induced with Streptococcus mutans on the dental amalgam-, Jap. J. Conserv. Dent., 21: 14-24, 1978. (in Japanese)

2) Kawabe, K.: Effectiveness of the artificial dental plaque induced from Streptococcus mutans to surface hardness of dental cements, Jap. J. Conserv. Dent., 21 : 267-278, 1978. (in Japanese)

3) Lui, J.L. and Low, T.: The surface finish of the new microfill restorative materials - A scanning electron microscope study-, J. Oral. Rehabil., 9: 67-82, 1982.

4) Marshall, K.C., Stout, M. and Mitchell, R.: Mechanism of the initial events in the sorption of marine bacteria to surface, J. Gent. Microb., 68: 337-348, 1971.

5) Sato, N. Futagami, M. Murakami, J., Ando, T., Kai, M., Hayashihara, H., Shintani, H. and Inoue, T.: Hydrophobic composite resin (Part I) Water sorption and solubility, J. Hiroshima Univ. Dent. Soc., 15: (in press) 1983. (in Japanese)

6) Ørstavik, D., Kraus, F.W. and Hewshaw, L.C.: In vitro attachment of Streptococci to the tooth surface, Infect. Immun., 9: 794-800, 1974.

7) Imura, M.: In vitro adherence of the plaque bacteria to the restorative materials-Effectiveness of variety of the restorative materials and acquired pellicle to the adherence of Streptococcus mutans-, Nihon Univ. Dent. J., 52: 707-719, 1978. (in Japanese)

8) Leach, S.A.: Dental plaque and surface interactions in the oral cavity, 5th ed., London Information Retrieval Co., 1980, pp. 159-183.

9) Clayton, J.A. and Green, E.: Roughness of pontic materials and dental plaque, J. Prosthet. Dent., 23: 407-411, 1970.

10) Gibbons, R.J. and van Houte, J.: On the formation of dental plaques, J. Periodontal., 44: 347-360, 1973. 
共に $\mathrm{Fe}_{3} \mathrm{O}_{4}$ が形成されるととを見出した。そとで, 上記 の仮説を検証するためと，乙れら 2 つの酸化物の酸化層 内における分布を明らかにするために XMA による状 態分析を試みた。この方法は, 数ミクロンの微小領域の 化学結合状態を調べるのに適した方法である。その結果，
結晶粒界に析出した酸化物は, $\mathrm{Fe}_{2} \mathrm{O}_{3}$ を芯として,その 周囲に $\mathrm{SnO}_{2}$ の鞘が形成するととが明らかになり, 上記 の仮説が証明された。また, $\mathrm{Fe}_{3} \mathrm{O}_{4}$ は, 酸化表面に近い 領域に多く分布しているととが明らかになった。

\title{
流し込み型床用レジンの粘弾性に颃よほす残留モノマーの影響
}

\author{
井上勝一郎, 藤井孝一, 池田 昭*, 杮内貞二* \\ 鹿児島大学歯学部歯科理工学講座 $*$ 鹿児島大学歯学部歯科補綴学第一講座
}

流し込み型の床用レジンは, 加熱重合型の床用レジン に比べて機械的強度が20 30\% 低下するといわれてい る。この理由の一つに, 残留モノマー量が加熱重合型の レジンの場合の数倍になっているととがあげられる。

本研究では, 現在比較的よく使用されている流し込み 型床用レジン 4 種類, 筆積法で使用される常温重合型レ ジン 1 種類について, それぞれ重合後, 重合体中に含ま れる残留モノマー量をガスクロマトグラフを用いて定量 し, 残留モノマーと動的粘弾性の関係を調べた。

さらに加熱重合型床用レジンについても同様の試験を
行ない, 流し込み型床用レジンの挙動と比較した。その 結果, 流し込み型床用レジン, 常温重合型レジンでは, 重合後の時間経過に伴なって残留モノマー量が減少し， それにつれて眝蔵弾性率 $\mathrm{E}^{\prime}$ あるいはガラス転移温度 $\mathrm{Tg}$ がわずかに上昇する傾向がみられた。しかしながら それらの上昇率は小さく, 流し込み型床用レジンあるい は常温重合型レジンを一度重合し, その後あらためて加 熱するという操作を加えた場合ほどの上昇はみられな かった。

疎水性コンポジットレジンへのプラーク付着について

新谷英章, 林原久盛, 村上淳子, 董 瑞香, 佐藤尚毅, 井上時雄

広島大学歯学部歯科保存学第一講座

Bis-MPEPP モノマーを有する疎水性コンポジットレ ジン Microrest は, 着色性, 吸水性が低く, 疎水基を有 する表面の利点が判明した。

今回, てのような踈水性表面に対して, 細菌々体がど のような付着を示すのかを in vitro 及び in vivo で検討 した。

Streptococcus mutans HS-6 と S. sanguis ATCC 10556 を用いた in vitro での付着実験では, Microrest は彷来
型レジンに比べ菌体付着が少なかった。S. mutans HS-6 による人工菌垢形成実験では, 差は認められなかった。 試料を口腔内に装着して, 口腔内レンサ球菌の付着を調 べたととろ Microrest は Clearfil に比へ, 付着菌数が 少なく, しかむ菌数が増加するのに時間を要した。

コンポジットレジン表面の疎水性がレンサ球菌の付着 を減少させているととが推察され, 表面の物理化学的性 状が, 細菌の付着に影響を及活すむのと考えられる。 